\title{
PHASE DIAGRAMS OF THE ELEMENTS
}





\section{Phase Diagrams of the Elements}

\section{David A. Young}


Permission has been granted by the publisher for the reprinting of Figure 15.17 from Solid State Physics by Neil W. Ashcroft and N. David Mermin, copyright $@ 1976$ by Saunders College Publishing, a division of Holt, Rinehart and Winston, Inc.

This book is a print-on-demand volume. It is manufactured using toner in place of ink.

Type and images may be less sharp than the same material seen in traditionally printed University of California Press editions.

\author{
University of California Press \\ Berkeley and Los Angeles, California \\ University of California Press \\ Oxford, England
}

Copyright $\odot 1991$ by The Regents of the University of California

Library of Congress Cataloging-in-Publication Data

\author{
Young, D. A. (David A.), 1942- \\ Phase diagrams of the elements/David A. Young \\ p. $\quad \mathrm{cm}$. \\ Includes bibliographical references and index. \\ ISBN 0-520-07483-1 \\ 1. Phase diagrams. 2. High pressure (Science) I. Title. \\ $\begin{array}{lr}\text { QD503.Y68 } 1991 & 90-25978 \\ 541.3^{\prime} 63-\mathrm{dc} 20 & \mathrm{CIP}\end{array}$
}

Printed in the United States of America

The paper used in this publication meets the minimum requirements of American National Standard for Information Sciences-Permanence of Paper for Printed Library Materials, ANSI Z39.48-1987@ 